\title{
Meningkatkan Kedisiplinan Guru Dalam Melaksanakan Tugas Melalui Penerapan Reward di SD Negeri 050745 Pangkalan Berandan Tahun Ajaran 2016/2017
}

\author{
Rosdiana \\ SD Negeri 050745 Pangkalan Berandan, Langkat, Sumatera Utara, \\ E-mail: rosdiana@gmail.com
}

\begin{abstract}
Abstrak
Penelitian Tindakan Sekolah ini bertujuan meningkatkan kedisiplinan guru. Subjek penelitian adalah 12 guru SD Negeri 050745 Berandan. Metode pengumpulan data melalui wawancara, observasi dan dokumentasi. Teknik analisis data yang digunakan adalah deskriptif kuantitatif dan kualitatif. Hasil pengamatan menunjukkan bahwa kedisiplinan guru mengalami peningkatan setiap harinya. Pada hari Senin (1) persentase kesiplinan guru adalah sebesar 33\% dan pada siklus I sebesar $75 \%$ dan pada siklus II sebesar $100 \%$. Pada hari ke dua berturut-turut peningkatannya adalah $47 \%$ siklus awal, 50\% siklus I dan $83 \%$ siklus II. Pada hari ke tiga berturut-turut $42 \%$ siklus awal, 75\% siklus I dan 92\% siklus II. Pada hari ke empat berturut-turut adalah 33\% siklus awal, 58\% siklus I, dan $82 \%$ siklus II. Kemudian pada hari ke lima persentase kedidiplinan guru berturut-turut adalah $25 \%$ siklus awal, $41,6 \%$ siklus I dan $75 \%$ siklus II dan pada hari ke enam $33 \%$ siklus awal, $67 \%$ siklus I dan $83 \%$ siklus II. Berdasarkan hal tersebut dapat dilihat bahwa dengan menerapkan Reward, kedisiplinan dalam melaksanakan tugas oleh Guru-guru SD Negeri 050745 angkalan Berandan akan mengalami peningkatan.
\end{abstract}

Kata Kunci: Kedisiplinan, reward

\section{Abstract}

The purpose of this study is to improve the student's skills in retelling the contents of the short story with Think Talk Write learning on students of SMP Negeri 1 Selesai academic year 2016/2017. This research is a classroom action research with qualitative descriptive research method consisting of 2 cycles. Each cycle consists of 4 stages namely, planning, implementation, observation and reflection. Data collection method used in this research is the result of observation in 
the field in the observation sheet. As the subject of the research is the students of class IX-6 SMP Negeri 1 Selesai consists of 32 students. In the first cycle, not all students are familiar with the Think Talk Write learning applied in retelling the contents of the short story. This can be seen from the average value obtained by students, in the early cycle of 75.2 with percentage of $71.9 \%$. In Cycle II, students begin to understand the Think Talk Write learning strategy in retelling the contents of the short story. This can be seen from the value of learning outcomes that experienced an increase of 82.8 with a percentage of 90.6\%. In this case, we can conclude that the students' skills in retelling the content of the short story is increased.

Keywords: Skills, Short Stories, Think Talk Write

\section{A. PENDAhULUAN}

Guru adalah teladan bagi peserta didiknya, setidaknya itulah makna tersirat dari Undang-Undang Guru dan Dosen nomor 14 Tahun 2005 pasal 1 ayat 1. Secara langsung maupun tidak langsung siswa akan belajar dari pengamatan dan kebiasaan yang dilihatnya setiap hari. Bagi anak, sekolah menjadi tempat belajar kedua setelah lingkungan keluarga. Sebagian besar waktu anak akan dihabiskan di sekolah, maka selayaknya seorang guru menjadi teladan yang baik (Undang-Undang Guru dan Dosen nomor 14 Tahun 2005 pasal 1).

Berdasarkan peraturan baik dari pemerintah pusat dan instansi Sekolah Dasar, sudah menjadi keharusan bagi para guru khususnya PNS untuk mentaati peraturan sesuai dengan Undang-Undang Guru dan Dosen nomor 14 tahun 2005 bab IV pasal 20. Seorang Pegawai Negeri Sipil harus bertanggung jawab secara penuh dan profesional pada kewajibannya, termasuk di dalamnya adalah ketepatan waktu kedatangan dalam bekerja. Sesuai dengan Undang-Undang Guru dan Dosen nomor 14 tahun 2005, bahwa seorang guru adalah pendidik profesional dengan tugas utama mendidik, mengajar, membimbing, mengarahkan, melatih, menilai, dan mengevaluasi peserta didik pada pendidikan anak usia dini jalur pendidikan formal, pendidikan dasar, dan pendidikan menengah. Seorang guru pegawai negeri menurut Undang-Undang nomor 43 Tahun 1999 pasal 1 ayat 1 tentang Pokok-Pokok 
Kepegawaian adalah setiap warga negara Republik Indonesia yang telah memenuhi syarat yang ditentukan, diangkat oleh pejabat yang berwenang dan diserahi tugas dalam suatu jabatan negara atau diserahi tugas negara lainnya, dan digaji berdasarkan peraturan perundang-undangan yang berlaku. Undang-Undang nomor 43 Tahun 1999 pasal 1 ayat 1 tentang Pokok-Pokok Kepegawaian jelas mendeskripsikan tugas guru sebagai pegawai negeri adalah sebuah tanggung jawab yang profesional. Profesional berarti bahwa pekerjaan atau kegiatan yang dilakukan oleh seseorang dan menjadi sumber penghasilan kehidupan yang memerlukan keahlian, kemahiran, atau kecakapan yang memenuhi standar mutu atau norma tertentu serta memerlukan pendidikan profesi (UndangUndang nomor 43 Tahun 1999 tentang Pokok-Pokok Kepegawaian pasal 1).

Tugas dan tanggung jawab guru sesuai dengan Permendiknas No.19 Tahun 2007 adalah sebagai agen pembelajaran yang memotivasi, memfasilitasi, mendidik, membimbing, dan melatih peserta didik sehingga menjadi manusia berkualitas dan mampu mengaktualisasikan potensi kemanusiaannya secara optimum. Tugas dan tanggung jawab guru terwujud dalam perilaku seharihari di sekolah. Perwujudan dari keteladanan yang ingin dicapai didukung dengan tata tertib yang ada di masing-masing sekolah (Permendiknas No. 19 Tahun 2007 tentang Standar Pengelolaan Pendidikan).

Tata tertib sekolah biasanya disusun untuk siswa maupun guru dan karyawan. Pemerintah melalui Permendiknas No. 19 Tahun 2007 menjelaskan bahwa tata tertib sekolah/madrasah ditetapkan oleh kepala sekolah/ madrasah melalui rapat dewan pendidik dengan mempertimbangkan masukan komite sekolah/madrasah, dan peserta didik. Tata tertib yang disusun sudah disepakati bersama untuk selanjutnya dapat dijalankan oleh seluruh warga sekolah. Dalam tata tertib disertai dengan punishment bagi yang melanggar. Namun kenyataanya punishment tersebut hanya berlaku bagi siswa saja. Berbeda halnya dengan guru dan karyawan, keberadaan punishment hanya sebatas formalitas (Permendiknas No. 19 Tahun 2007 tentang Standar Pengelolaan Pendidikan).

Kurang maksimalnya disiplin dikalangan guru yang cukup memprihatinkan adalah perihal kedatangan guru di sekolah. 
Sebagai seorang pegawai negeri yang sudah menerima hak finansial secara penuh, wajib melaksanakan tugas dan kewajibannya. Termasuk kewajibannya untuk mentaati peraturan atau tata tertib yang berlaku di sekolah. Kedisiplinan guru dalam melaksanakan tugas merupakan suatu hal yang belum dapat diselesaikan permasalahannya secara maksimal terutama jam masuk sekolah di sekolah-sekolah yang berada di pedesaan. Faktor jarak dan lokasi sekolah menjadi beberapa alasan keterlambatan. Keterlambatan guru masuk ke sekolah menggambarkan belum terbentuknya sikap guru yang berkualitas dan profesional. Tulisan ini mendeskripsikan tentang kedisiplinan guru dalam melaksanakan tugas melalui penerapan reward.

\section{B. TINJAUAN PUSTAKA \\ 1. Pengertian Pendidikan}

Pendidikan adalah usaha sadar yang dengan sengaja dirancangkan untuk mencapai tujuan yang telah ditetapkan. Pendidikan bertujuan untuk meningkatkan kualitas sumber daya manusia. Dalam usaha meningkatkan kualitas sumber daya pendidikan, guru merupakan komponen sumber daya manusia yang harus dibina dan dikembangkan terus-menerus. Potensi sumber daya guru itu perlu terus tumbuh dan berkembang agar dapat melakukan fungsinya secara potensial. Selain itu pengaruh perubahan yang serba cepat menuntut guru-guru untuk terus-menerus belajar menyesuaikan diri dengan perkembangan ilmu pengetahuan dan teknologi serta mobilitas masyarakat.

Masyarakat mempercayai, mengakui dan menyerahkan kepada guru untuk mendidik tunas-tunas muda dan membantu mengembangkan potensinya secara professional. Kepercayaan, keyakinan, dan penerimaan ini merupakan substansi dari pengakuan masyarakat terhadap profesi guru. Implikasi dari pengakuan tersebut mensyaratkan guru harus memiliki kualitas yang memadai. Tidak hanya pada tataran normatif saja namun mampu mengembangkan kompetensi yang dimiliki, baik kompetensi personal, professional, maupun kemasyarakatan dalam selubung aktualisasi kebijakan pendidikan.

Profesionalisme menjadi tuntutan dari setiap pekerjaan. Apalagi profesi guru yang sehari-hari menangani benda hidup berupa siswa dengan berbagai karakteristik yang masing-masing tidak sama. 
Pekerjaaan sebagai guru menjadi lebih berat tatkala menyangkut peningkatan kemampuan anak didiknya, sedangkan kemampuan dirinya mengalami stagnasi.

Guru yang profesional adalah mereka yang memiliki kemampuan profesional dengan berbagai kapasitasnya sebagai pendidik. Studi yang dilakukan oleh Ace Suryani menunjukkan bahwa Guru yang bermutu dapat diukur dengan lima indikator, yaitu: pertama, kemampuan profesional (professional capacity), sebagaimana terukur dari ijazah, jenjang pendidikan, jabatan dan golongan, serta pelatihan. Kedua, upaya profesional (professional efforts), sebagaimana terukur dari kegiatan mengajar, pengabdian dan penelitian. Ketiga, waktu yang dicurahkan untuk kegiatan profesional (teacher's time), sebagaimana terukur dari masa jabatan, pengalaman mengajar serta lainnya. Keempat, kesesuaian antara keahlian dan pekerjaannya (link and match), sebagaimana terukur dari mata pelajaran yang diampu, apakah telah sesuai dengan spesialisasinya atau tidak, serta kelima, tingkat kesejahteraan (prosperiousity) sebagaimana terukur dari upah, honor atau penghasilan rutinnya. Tingkat kesejahteraan yang rendah bisa mendorong seorang pendidik untuk melakukan kerja sambilan, dan bilamana kerja sambilan ini sukses, bisa jadi profesi mengajarnya berubah menjadi sambilan.

Guru yang profesional amat berarti bagi pembentukan sekolah unggulan. Guru profesional memiliki pengalaman mengajar, kapasitas intelektual, moral, keimanan, ketaqwaan, disiplin, tanggungjawab, wawasan kependidikan yang luas, kemampuan manajerial, trampil, kreatif, memiliki keterbukaan profesional dalam memahami potensi, karakteristik dan masalah perkembangan peserta didik, mampu mengembangkan rencana studi dan karir peserta didik serta memiliki kemampuan meneliti dan mengembangkan kurikulum.

Makin kuatnya tuntutan akan profesionalisme guru bukan hanya berlangsung di Indonesia, melainkan di negara-negara maju. Seperti Amerika Serikat, isu tentang profesionalisme guru ramai dibicarakan pada pertengahan tahun 1980-an. Jurnal terkemuka manajemen pendidikan, Educational Leadership edisi Maret 1933 menurunkan laporan mengenai tuntutan guru professional.

Menurut Jurnal tersebut, untuk menjadi professional, seorang guru dituntut memiliki lima hal. Pertama, guru mempunyai komitmen pada siswa dan proses belajarnya. Ini berarti bahwa komitmen 
tertinggi guru adalah kepada kepentingan siswanya. Kedua, guru menguasai secara mendalam bahan/mata pelajaran yang diajarkan serta cara mengajarkannya kepada siswa. Bagi guru, hal ini meryupakan dua hal yang tidak dapat dipisahkan. Ketiga, guru bertanggung jawab memantau hasil belajar siswa melalui berbagai teknik evaluasi, mulai cara pengamatan dalam perilaku siswa sampau tes hasil belajar. Keempat, guru mampu berpikir sistematis tentang apa yang dilakukannya, dan belajar dari pengalamannya. Artinya, harus selalu ada waktu untuk guru guna mengadakan refleksi dan koreksi terhadap apa yang telah dilakukannya. Untuk bisa belajar dari pengalaman, ia harus tahu mana yang benar dan salah, serta baik dan buruk dampaknya pada proses belajar siswa. Kelima, guru seyogianya merupakan bagian dari masyarakat belajar dalam lingkungan profesinya, misalnya PGRI dan organisasi profesi lainnya (Supriadi, 1999:98).

\section{Pengertian Guru}

Secara etimologi (asal usul kata), istilah "Guru" berasal dari bahasa India yang artinya orang yang mengajarkan tentang kelepasan dari sengsara" Shambuan, Republika, (dalam Suparlan 2005:11). Kemudian Rabindranath Tagore (dalam Suparlan 2005:11) menggunakan istilah Shanti Niketan atau rumah damai untuk tempat para guru mengamalkan tugas mulianya membangun spiritualitas anak-anak bangsa di India (spiritual intelligence).

Pengertian guru kemudian menjadi semakin luas, tidak hanya terbatas dalam kegiatan keilmuan yang bersifat kecerdasan spiritual (spiritual intelligence) dan kecerdasan intelektual (intellectual intelligence), tetapi juga menyangkut kecerdasan kinestetik jasmaniah (bodily kinesthetic), seperti guru tari, guru olah raga, guru senam dan guru musik. Dengan demikian, guru dapat diartikan sebagai orang yang tugasnya terkait dengan upaya mencerdaskan kehidupan bangsa dalam semua aspeknya, baik spiritual dan emosional, intelektual, fisikal, maupun aspek lainnya.

Poerwadarminta (dalam Suparlan 2005:13) menyatakan, "guru adalah orang yang kerjanya mengajar." Dengan definisi ini, guru disamakan dengan pengajar. Pengertian guru ini hanya menyebutkan satu sisi yaitu sebagai pengajar, tidak termasuk pengertian guru sebagai pendidik dan pelatih. Selanjutnya, Zakiyah Daradjat (dalam 
Suparlan, 2005:13) menyatakan," guru adalah pendidik profesional karena guru telah menerima dan memikul beban dari orang tua untuk ikut mendidik anak-anak."

UU Guru dan Dosen Republik Indonesia No.14 Tahun 2005 "Guru adalah pendidik profesional dengan tugas utama mendidik, mengajar, membimbing, mengarahkan, melatih, menilai, dan mengevaluasi peserta didik pada pendidikan anak usia dini jalur pendidikan formal, pendidikan dasar, dan pendidikan menengah".

Selanjutnya UU No.20 Tahun 2003 pasal 39 ayat 2 tentang sistem pendidikan nasional menyatakan,"pendidik merupakan tenaga profesional yang bertugas merencanakan dan melaksanakan proses pembelajaran, menilai hasil pembelajaran, melakukan pembimbingan dan pelatihan, serta melakukan penelitian dan pengabdian kepada masyarakat, terutama bagi pendidik pada perguruan tinggi."

PP No.19 Tahun 2005 tentang Standar Nasional Pendidikan menyatakan,"pendidik (guru) harus memiliki kualifikasi akademik dan kompetensi sebagai agen pembelajaran, sehat jasmani dan rohani, serta memiliki kemampuan untuk mewujudkan tujuan pendidikan nasional."

Berdasarkan definisi di atas, dapat disimpulkan bahwa guru adalah tenaga pendidik yang profesional dengan tugas utama mendidik, mengajar, membimbing, mengarahkan, melatih, menilai dan mengevaluasi peserta didik, dan bertugas merencanakan dan melaksanakan proses pembelajaran.

\section{Kedisiplinan}

Menurut Suwandi dan Sanjari (2009:11-12) menjelaskan secara rinci mengenai pengertian disiplin sebagai berikut.

- Latihan yang memperkuat

Disiplin dikaitkan dengan latihan yang memperkuat, terutama ditekankan pada pikiran dan watak untuk menghasilkan kendali diri, kebiasaan untuk patuh dan sebagainya. Latihanlatihan dalam rangka menghasilkan kebiasaan patuh dapat dilihat pada penanaman disiplin di kalangan Angkatan Bersenjata. Ibadah puasa dapat digolongkan sebagai suatu latihan dalam arti penanaman disiplin yang tujuannya untuk mempertinggi daya kendali diri.

- Koreksi dan sanksi

Arti disiplin dalam kaitannya dengan koreksi dan sanksi terutama diperlukan dalam suatu lembaga yang telah mempunyai tata tertib 
yang baik. Bagi yang melanggar tata tertib dapat dilakukan dua macam tindakan, yaitu berupa koreksi untuk memperbaiki kesalahan dan sanksi. Keduanya harus dilaksanakan secara konsisten untuk mencegah terjadinya penyimpangan dan pelanggaran terhadap norma dan kaidah yang telah disepakati bersama.

- Kendali atau terciptanya ketertiban dan keteraturan

Orang-orang yang berdisiplin adalah orang-orang yang mampu mengendalikan dirinya. Demikian ketertiban masyarakat, pembinaan disiplin harus disesuaikan dengan tingkat perkembangan teknologi dan tingkat perkembangan masyarakat. Perpaduan antara ketertiban dan keteraturan menghasilkan suatu aturan tata laku.

- Sistem aturan dan tata laku

Setiap kelompok manusia masyarakat atau bangsa selalu terikat pada berbagai peraturan yang mengatur hubungan sesama anggotanya maupun masyarakat, bangsa atau negara. Manusia dari masyarakat wajib berperilaku baik yang formal, non formal maupun yang disepakati, jika ingin masyarakat atau bangsa itu disebut berdisiplin.

Menurut Suwandi dan Sanjari (2009:34) guru dikatakan mengajar dengan disiplin apabila telah mentaati semua peraturan atau tata tertib di sekolah, suatu sikap yang meliputi:

\section{a. Keaktifan masuk sekolah}

Aktif masuk sekolah berarti aktif atau rajin masuk sekolah, sepanjang, dalam keadaan sehat atau tidak sakit. Guru yang aktif akan mementingkan sekolahnya walaupun ada kepentingan keluarga sekalipun, sikap ini didasari oleh disiplin diri dan tidak menyiakan waktu sehingga tidak merugi.

\section{b. Ketertiban di dalam kelas}

Di dalam tata tertib sekolah telah disebutkan bahwa kewajiban guru adalah "ikut membantu agar tata tertib sekolah dapat berjalan dari ditaati" juga disebutkan dalam larangan guru yaitu "mengganggu jalannya kegiatan bela jar mengajar dalam kelasnya maupun terhadap kelas lain". Dengan sikap ini maka pengajaran tidak akan terhambat, karena guru tidak mengganggu jalannya proses kegiatan belajar mengajar dan dengan kesadaran akan selalu menciptakan ketertiban di dalam kelas maupun sekolahnya. Hal ini berpengaruh terhadap kelancaran proses belajar mengajar.

\section{c. Keaktifan memberikan materi ajar sesuai dengan Rencana Pelaksanaan}


Pembelajaran di Kelas yang ditentukan dalam juknis yang bernama RPP. Guru akan selalu memberikan materi ajar sesuai dengan jam dan jadwal pelajaran di kelas sejak awal sampai berakhir jam pelajaran. Dengan demikian tidak satupun materi ajar yang diabaikan, sehingga prestasi mengajar juga akan dapat dicapai secara menyeluruh dengan mutu yang baik.

\section{Reward and Punishment}

Metode reward (ganjaran) dan punishment (hukuman) merupakan suatu bentuk teori penguatan positif yang bersumber dari teori Behavioristik. Menurut teori Behavioristik belajar adalah perubahan tingkah laku sebagai akibat dari adanya interaksi antara stimulus dan respon. Dengan kata lain, belajar merupakan bentuk perubahan yang dialami siswa dalam hal kemampuannya untuk bertingkah laku dengan cara yang baru sebagai hasil interaksi antara stimulus dan respon (Budiningsih, 2010). Menurut Purwanto (2012) "reward (ganjaran) ialah alat untuk mendidik anakanak supaya anak dapat merasa senang karena perbuatan a tau pekerjaannya mendapat penghargaan". Sedangkan menurut Indrakusuma (2008) "reward (ganjaran) adalah penilaian yang bersifat positif terhadap belajarnya siswa".

Dari beberapa pendapat di atas, dapat disimpulkan bahwa reward (ganjaran) adalah segala sesuatu yang berupa penghargaan yang menyenangkan perasaan yang diberikan kepada siswa karena mendapat hasil baik dalam proses pendidikannya dengan tujuan agar senantiasa melakukan pekerjaan yang baik dan terpuji. Peranan reward (ganjaran) dalam proses pengajaran cukup penting terutama sebagai faktor eksternal dalam mempengaruhi dan mengarahkan perilaku guru. Hal ini berdasarkan atas berbagai pertimbangan logis, diantaranya reward (ganjaran) biasanya dapat menimbulkan motivasi, dan reward (ganjaran) juga memiliki pengaruh positif dalam kehidupan guru.

Penerapan disiplin dapat ditegakan melalui pemberian reward and punishment. Reward dan punishment merupakan dua bentuk metode dalam memotivasi seseorang untuk melakukan kebaikan dan meningkatkan prestasinya. Kedua metode ini sudah cukup lama dikenal dalam dunia kerja. Tidak hanya dalam dunia kerja, dalam dunia penidikan pun kedua ini kerap kali digunakan. Namun 
selalu terjadi perbedaan pandangan, mana yang lebih diprioritaskan antara reward dengan punishment? Rewardartinya ganjaran, hadiah, penghargaan atau imbalan. Dalam konsep manajemen, reward merupakan salah satu alat untuk peningkatan motivasi para pegawai. Metode ini bisa meng-asosiasi-kan perbuatan dan kelakuan seseorang dengan perasaan bahagia, senang, dan biasanya akan membuat mereka melakukan suatu perbuatan yang baik secara berulanglang. Selain motivasi, reward juga bertujuan agar seseorang menjadi giat lagi usahanya untuk memperbaiki atau meningkatkan prestasi yang telah dapat dicapainya.

Sementara punishment diartikan sebagai hukuman atau sanksi. Jika reward merupakan bentuk reinforcement yang positif, maka punishment sebagai bentuk reinforcement yang negatif, tetapi kalau diberikan secara tepat dan bijak bisa menjadi alat motivasi.

Menurut Indrakusuma (2009) reward (ganjaran) yang diberikan kepada guru bentuknya bermacam-macam, secara garis besar reward (ganjaran) dapat dibedakan menjadi empat macam.

\section{a. Pujian}

Pujian adalah satu bentuk reward (ganjaran) yang paling mudah dilakukan. Pujian dapat berupa kata-kata seperti: baik, bagus, bagus sekali dan sebagainya, tetapi dapat juga berupa katakata yang bersifat sugesti.

\section{b. Penghormatan}

Reward (ganjaran) yang berupa penghormatan ini dapat berbentuk dua macam pula. Pertama, berbentuk semacam penobatan. Kedua, penghormatan yang berbentuk pemberian kekuasaan untuk melakukan sesuatu.

\section{c. Hadiah}

Yang dimaksud dengan hadiah di sini ialah reward yang berbentuk pemberian yang berupa barang. Reward yang berupa pemberian barang ini disebut juga reward materiil.

\section{d. Tanda Penghargaan}

Jika hadiah adalah reward (ganjaran) yang berupa barang, maka tanda penghargaan adalah kebalikannya. Tanda penghargaan tidak dinilai dari segi harga dan kegunaan barang-barang tersebut, seperti halnya pada hadiah. Melainkan, tanda pengahargaan dinilai dari segi "kesan" atau "nilai kenang"nya. Oleh karena tanda 
penghargaan ini disebut juga reward simbolis yang dapat berupa suratsurat tanda jasa, sertifikat-sertifikat.

Dari keempat macam reward (ganjaran) tersebut di atas, dalam penerapannya seorang guru dapat memilih bentuk macammacam reward (ganjaran) yang cocok dengan guru dan disesuaikan dengan situasi dan kondisi, baik situasi dan kondisi siswa atau situasi dan kondisi keuangan, bila hal itu menyangkut masalah keuangan.

\section{METODE}

1. Lokasi dan Waktu Penelitian

Lokasi penelitian adalah di SD Negeri 050745 Pangkalan Berandan yang beralamat di Pangkalan Berandan Kecamatan Babalan Kabupaten Langkat. Waktu pelaksanaan selama dua bulan mulai Februari s/d Maret 2017.

\section{Personalia}

Penelitian ini dilaksanakan sendiri oleh Tim Pengembang SD Negeri 050745 Pangkalan Berandan yang terdiri dari Kepala Sekolah, Wakil Kepala Sekolah dan PKS Kurikulum.

\section{Perencanaan Tindakan}

Penelitian ini dilakukan dengan metode penelitian tindakan kelas yang berlangsung selama 2 siklus. Masing-masing siklus terdiri dari tahapan perencanaan, pelaksanaan, observasi dan refleksi. Metode penelitian yang dilakukan adalah dengan melaksanakan supervisi akademik yang meliputi supervisi tradisional dan supervisi klinis.

a. Perencanaan

Peneliti merencanakan kegiatan/ metode yang akan digunakan yaitu penerapan reward. Selanjutnya, menyusun rancangan/ langkahlangkah kegiatan termasuk mempertegas aturan dalam penelitian sebagai berikut.

$\checkmark$ Jam kedatangan guru di sekolah menurut jadwal di sekolah adalah pukul 07.00 WIB, maka guru yang tepat waktu masuk sekolah adalah guru yang datang sebelum pukul 06.59 WIB.

$\checkmark$ Reward diberikan kepada guru pada saat guru tiba di sekolah dan di ruang guru.

$\checkmark$ Peneliti melakukan konfirmasi dengan pihak sekolah mengenai prosedur tindakan dalam penelitian yang akan 
dilakukan sehari sebelum dilakukan penelitian. Selain itu peneliti juga menyiapkan format observasi.

b. Pelaksanaan tindakan

Pelaksanaan tindakan terdiri dari:

$\checkmark$ Peneliti mengamati dan mencatat waktu kedatangan guru,

$\checkmark$ Pengawas memberikan reward sesuai dengan skenario yang telah disusun peneliti.

c. Observasi

Melakukan observasi dengan menggunakan format observasi yang terdiri dari 2 jenis instrumen. Instrumen pertama adalah lembar pengamatan kedatangan guru SD, terdiri dari 6 kolom kedatangan guru SD yang akan diisi setiap hari selama 6 hari pada penelitian tindakan siklus 1 .

d. Refleksi

Refleksi terdiri dari:

$\checkmark$ Melakukan evaluasi tindakan yang telah dilakukan yaitu peningkatan kedisiplinan yang dilakukan dengan skenario,

$\checkmark$ Memperbaiki pelaksanaan tindakan sesuai dengan hasil evaluasi, untuk digunakan pada siklus berikutnya

4. Instrumen

Instrumen yang digunakan berupa lembar pengamatan seperti pada Tabel 1.

Tabel 1 Format Lembar Pengamatan Kedatangan Guru

\begin{tabular}{|c|c|c|c|c|c|c|c|}
\hline \multirow{2}{*}{ No } & \multirow{2}{*}{ Nama Guru } & \multicolumn{6}{|c|}{ Hari } \\
\hline & & $\mathrm{I}$ & II & III & IV & $\mathrm{V}$ & VI \\
\hline & & & & & & & \\
\hline & & & & & & & \\
\hline & & & & & & & \\
\hline \multicolumn{2}{|c|}{ Persentase keterlambatan } & & & & & & \\
\hline
\end{tabular}


Kriteria keberhasilan apabila tingkat keberhasilan peningkatan kedisiplinan guru dapat meningkat sebesar $80 \%$. Bentuk tindakan dalam penelitian ini berupa treatment kepada guru-guru melalui penerapan reward berupa pernyataan seperti dalam Tabel 2 .

\section{Tabel 2 Bentuk Reward}

\begin{tabular}{|c|l|}
\hline No & Bentuk kata-kata/kalimat reward \\
\hline 1 & "top pak/bu" (menunjjkkan ibu jari) \\
\hline 2 & "anda keranpak/bu, hari ini tidak terlambat" \\
\hline 3 & "wah, semakin pagi semakin terlihat fresh" \\
\hline 4 & "bapak/ibu hari tiba lebih pagi hari ini, bagus pak/bu" \\
\hline 5 & "bapak/ibu hari ini tidak kala lho sama murid-murid" \\
\hline 6 & "sip pak/bu, hari ini tidak terlambat" \\
\hline 7 & "selamat pagi bapak/ibu guru teladan" \\
\hline 8 & "dua jempol pak/bu, untuk kedatanganny pagi ini" \\
\hline
\end{tabular}

\section{Analisa Data}

Analisis data dalam penelitian ini adalah berupa analisis berdasarkan prosentase hasil penelitian dan disajikan dengan deskriptif berupa kalimat. Data hasil pengamatan dimasukkan ke dalam rumus deskriptif persentase sebagai berikut.

\section{Keterangan:}

$$
\mathrm{DP}=\frac{n}{N} \times 100 \%
$$

DP: Deskriptif Persentase

$\mathrm{n}$ : skor yang diperoleh

$\mathrm{N}$ : Jumlah total skor

\section{Indikator Keberhasilan}

Berdasarkan kerangka berpikir yang telah dimuat di atas adapun indikator keberhasilan adalah dikatakan berhasil apabila $75 \%$ dari jumlah guru sudah disiplin pada siklus II setiap harinya

\section{HASIL DAN PEMBAHASAN \\ 1. Hasil}

Pada pra-Siklus, masih banyak guru yang belum disiplin dalam melaksanakan tugas. Hal itu terlihat dari seringnya para guru terlambat masuk kelas yang mengakibatkan siswa dari beberapa kelas 
menimbulkan keributan dan mengganggu para siswa dari kelas lain yang sedang belajar. Selain itu proses belajar mengajarpun tidak berjalan dengan baik. Waktu yang tersedia sebenarnya cukup untuk membantu siswa menguasai materi yang akan dipelajari pada hari itu, akan tetapi karena guru tidak tepat waktu hadir didalam kelas, materi pembelajaran yang disampaikan hanya garis-garis besarnya saja tanpa penjelasan memadai, sehingga informasi yang diperoleh siswa kurang dan berdampak pada hasil belajar siswa.

Berdasarkan hasil pengamatan sejak pra-Siklus sampai dengan Siklus II terjadi peningkatan disiplin untuk setiap nama harinya, misalnya setiap hari Senin 33,33\% menjadi 75\% dan 100. Sedangkan per pekannya terjadi fluktuasi seperti tertera pada Tabel 3.

Tabel 3 Hasil Pengamatan Kedisiplinan Guru

\begin{tabular}{|c|c|c|c|}
\hline Hari & Pra-Siklus & Siklus I & Siklus II \\
\hline I & $33,33 \%$ & $75 \%$ & $100 \%$ \\
\hline II & $46,66 \%$ & $50 \%$ & $83,33 \%$ \\
\hline III & $41,66 \%$ & $75 \%$ & $91,66 \%$ \\
\hline IV & $33,33 \%$ & $58,33 \%$ & $82,33 \%$ \\
\hline V & $25 \%$ & $41,66 \%$ & $75 \%$ \\
\hline VI & $33,33 \%$ & $66,66 \%$ & $83,33 \%$ \\
\hline Rata-rata & $\mathbf{3 5 , 5 5 \%}$ & $\mathbf{6 1 , 1 0 \%}$ & $\mathbf{8 5 , 9 4 \%}$ \\
\hline
\end{tabular}

\section{Pembahasan}

\subsection{Hasil Pengamatan Sebelum Diterapkan Reward}

Jumlah guru yang hadir tepat waktu lebih sedikit dibanding jumlah guru yang terlambat. Persentase ketidakterlambatan rata-rata sekitar 4 guru $(35,55 \%)$. Banyak sekali alasan yang digunakan guru jika ditanya mengapa bisa terlambat. Hal ini mengakibatkan banyak siswa yang keluar kelas dikarenakan guru yang bersangkutan tidak tepat waktu masuk kelas sesuai jadwal.

\subsection{Hasil Pengamatan Setelah Diterapkan Reward Pada Siklus I}

Tingkat kehadiran guru sebelum pukul 07.00 WIB mengalami peningkatan. Hal itu terlihat dari jumlah kehadiran tepat waktu yang meningkat setiap harinya rata 7 guru $(61,10 \%)$. Ternyata melalui metode Reward mampu membangkitkan semangat para guru untuk 
bisa hadir tepat waktu sehingga proses belajar-mengajar bisa berjalan dengan baik sesuai dengan waktu yang telah ditentukan.

\subsection{Hasil Pengamatan Setelah Diterapkan Reward Pada Siklus II}

Ketepatan waktu guru hadir di sekolah semakin meningkat rata-rata 10 guru $(85,94 \%)$ walaupun terjadi fluktuasi. Kehadiran semua 12 guru (100\%) masih terjadi hanya pada hari pertama, Senin, karena merupakan kegiatan rutin upacara penaikan bendera. Hal itu terlihat dari persentase guru yang tidak terlambat meningkat. Dengan meningkatnya persentase kehadiran tepat waktu guru membuktikan bahwa melalui penerapan metode Reward guru termotivasi dan semangat untuk bisa hadir tepat waktu sehingga proses belajar mengajar bisa berjalan dengan baik sesuai dengan waktu yang telah ditentukan dan siswa tidak lagi keluar kelas menunggu kedatangan guru yang terlambat.

\section{E. SIMPULAN}

\section{Kesimpulan}

Berdasarkan hasil Penelitian Tindakan Sekolah (PTS) dapat disimpulkan sebagai berikut. Pertama, melalui penerapan Reward dapat meningkatkan motivasi guru dalam meningkatkan kedisiplianan terutama dalam kehadiran tepat waktu disekolah. Guru menunjukkan sikap keseriusan dan semangat yang tinggi untuk dpat memberikan teladan yang baik kepada siswa. Informasi ini peneliti peroleh dari hasil pengamatan pada saat mengadakan wawancara kepada para guru. Kedua, melalui penerapan Reward dapat meningkatkan kompetensi guru dan kesadaran guru betapa pentingnya untuk hadir tepat waktu didalam kelas. Hal itu dapat dibuktikan dari hasil pengamatan yang memperlihatkan bahwa terjadi peningkatan dari siklus ke siklus .

\section{Saran}

Saran sebagai tindak lanjut dari hasil kesimpulan adalah: pertama, motivasi yang sudah tertanam khususnya hendaknya terus dipertahankan dan ditingkatkan/dikembangkan. Kedua, hendaknya kedisiplinan yang sudah terbentuk dapat diterapkan untuk masa yang akan datang untuk setiap harinya, tidak hanya pada hari Senin. 


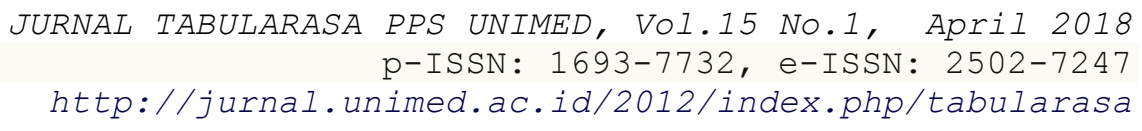

\section{F. DAFTAR PUSTAKA}

Budiningsih, A. 2009. Belajar dan Pembelajaran. Jakarta: Rineka Cipta.

Indrakusuma, A. 2010. Pengantar Ilmu Pendidikan. Surabaya: Usaha Nasional.

Purwanto. 2013. Evaluasi Hasil Belajar. Yogyakarta:Pustaka Belajar. Suparlan. 2005. Menjadi Guru Efektif. Yogyakarta: Hikayat.

Suwandi dan Sajari.2009. Memahami Penelitian Kualitatif. Jakarta: Rineka Cipta. 